\title{
Buriti palm fiber (Mauritia flexuosa MART.): characterization and studies for its application in design products
}

\author{
Ivete Maria Cattani ${ }^{1, a^{*}}$ and Júlia Baruque Ramos ${ }^{2, b}$ \\ 1,2Universtiy of Sao Paulo - School of Arts, Sciences and Humanities - \\ Av. Arlindo Bettio 1000-03828000 - São Paulo - SP - Brazil \\ aivetecattani@usp.br*, bjbaruque@usp.br
}

Keywords: buriti palm, characterization, design.

\begin{abstract}
Buriti (Mauritia flexuosa Mart.) is the most common and abundant palm tree in the Brazilian territory and it is present throughout South America. It is known as the "Tree of Life", because everything in it can be used and many residents of rural communities have this palm tree as their main source of income. In different Brazilian states, the fibers removed from young leaves of the Buriti palm tree are employed in the manufacturing of handicraft, being this fiber popularly known as "flax or silk" of buriti. In order to apply the "flax or silk" of buriti in new products, it is necessary to study their physiochemical characteristics, as well as to monitor the handling of the palm tree, the extraction process of the fiber and its application in handmade products. The buriti fiber analyzed in this study is from the Brazilian Cerrado biome, more specifically from the town of Barreirinhas (Maranhão State). The fibers were tested in order to determine tensile rupture strength, tenacity, elongation, Young's modulus, cross microscopic structure and regain. In order to carry out the tests, the fibers were separated in 5 groups: 1) in natura fibers, 2) fibers boiled by the origin community, 3) fibers boiled in bleach, 4) fibers boiled in softener, and 5) fibers boiled in lemon juice, being the processing of last three groups done in the city of São Paulo. The group used for cross and longitudinal microscopy was in natura fibers. The groups of fibers referred were also maintained in water at $37^{\circ} \mathrm{C}$ for 21 days to determine its reaction and resistance to weather and were analyzed every 3 days. The results of tenacity, elongation and Young's modulus for each group were respectively: 1) $28.4 \pm 5.6 \mathrm{cN} /$ tex $(\mathrm{CV}=20 \%), 8.3 \pm 0.6 \%(\mathrm{CV}=7 \%), 6.1 \pm 0.8 \mathrm{~N} / \mathrm{tex}(\mathrm{CV}=13 \%)$; 2) $31.0 \pm 7.7 \mathrm{cN} /$ tex $(\mathrm{CV}=25 \%), 8.4 \pm 0.8 \%(\mathrm{CV}=9 \%), 7.2 \pm 0.7 \mathrm{~N} /$ tex $(\mathrm{CV}=10 \%)$; 3) $27.6 \pm 7.2 \mathrm{cN} / \mathrm{tex}$ $(\mathrm{CV}=26 \%), 7.9 \pm 0.6 \% \quad(\mathrm{CV}=7 \%), 6.0 \pm 1.2 \mathrm{~N} / \mathrm{tex} \quad(\mathrm{CV}=20 \%) ; 4) 22.1 \pm 8.8 \mathrm{cN} / \mathrm{tex}(\mathrm{CV}=40 \%)$, $8.6 \pm 1.9 \% \quad(\mathrm{CV}=22 \%), 5.0 \pm 1.0 \mathrm{~N} / \mathrm{tex} \quad(\mathrm{CV}=20 \%) ; 5) \quad 29.7 \pm 6.5 \mathrm{cN} /$ tex $(\mathrm{CV}=22 \%), 8.6 \pm 0.6 \%$ $(\mathrm{CV}=7 \%), 5.8 \pm 0.8 \mathrm{~N} /$ tex $(\mathrm{CV}=13 \%)$. Through this study it could be possible to expand knowledge regarding the potential of the Brazilian biodiversity, presenting applications for the buriti fiber in the development of new products to be employed in design and industry as well as collaborating in the construction of social benefits by encouraging the recovery and strengthening of local cultural identity, community organization around solidarity economy and consequent generation of income for fibers extractive communities.
\end{abstract}

\section{Introduction}

\begin{abstract}
"Andamos por aí vendo o ribeiro, o qual é de muita água e muito boa. Ao longo dele há muitas palmeiras, não muito altas; e muito bons palmitos. Colhemos e comemos muitos deles."[1] ("We walked around seeing the river, which is a lot of water and very good. Along it there are many palm trees, not very high; very good and palmettos. We pick and eat many of them" - author's free translation)
\end{abstract}

Brazil, country of continental size, is internationally known for its biodiversity and its natural potential applicable in different areas. The Brazilian territory has $60 \%$ of the total area of 5.5 million $\mathrm{km}^{2}$ that comprises the Amazon Rainforest, the largest tropical forest in the world. This 
forest is considered the largest reservoir of biodiversity on the planet: from 100,000 species of plants in Latin America, 30,000 are in the region, besides 2,500 species of trees and a rich fauna [2]. Brazil is one of the countries included among the so-called megadiversity, i.e., the group of 12 nations that has $70 \%$ of the total biodiversity of the planet [3]. Because of its territorial extension, approximately 8.5 million $\mathrm{km}^{2}$, the country has large differences in climate and ecological variations, forming distinct biogeographic zones or biomes. Also noteworthy is the sociobiodiversity found in Brazil, represented by 200 indigenous folks and various communities as "quilombolas" (descendants of runaway slaves), "caiçaras" (fishermen) and "seringueiros" (latex collectors) - which bring together an invaluable collection of traditional knowledge on the conservation of biodiversity [4]. This natural multiplicity and knowledge found in the country highlights the importance of the development of research in search of a better use of Brazilian biodiversity and sociobiodiversity. In recent years, increasing attention to environmental issues has promoted the increase in research on composites using natural fibers as reinforcing fillers [5]. However, these new demands require radical rethink of the current model of consumption and point to the need to verify the environmental benefits along together the economic and competitive ones to the market and thus intervene with a systemic view, individualizing every 'eco-efficiency' opportunity [6].

Brazilian industry in general has invested in redirection of its production mode and considers the transition to an environmentally sustainable and socially inclusive economy compatible with the goals of economic growth and improvement of competitiveness [7]. In this scenario new opportunities for sustainable employment of Brazilian biodiversity, the creative impulse of the entrepreneur is of great importance since it is up to him to imagine a product or service that offers more satisfaction to the needs with fewer resources and work; the creativity will allow the researcher increasingly find elegant solutions to increasingly complex problems [8]. In this context the present study is set through the research about the fiber removed from Buriti palm (Mauritia flexuosa Mart.).

“Minha terra tem palmeiras..." [9] (“My land has palm trees..." - author's free translation)

Considered the most beautiful plants in the plant kingdom, the palm trees are represented by about 1,500 species, grouped in about 200 genera [10]. Of historical importance in the survival and development of civilizations, the palm trees are among the oldest plants of the globe and their vestiges dating back over 120 million years. As described by Bondar [11]: "Grow in good soil, suitable for agriculture. Also they are adapted to acidic, siliceous, barren soils, where no economic cultivated plant could thrive. They grow in swamps, as well as in dry rocks without any soil decomposed".

This plant is distinguished by elegant bearing and also by the different products originated from it. Citing some examples, many native species provide palmettos, other ones from its almonds provide edible and industrial oil, among many benefits from this plant that is found throughout the national territory [12].

The Buriti Palm (Mauritia flexuosa Mart.) is one of the most important and perhaps the one that since prehistoric times, the aborigines are taking greater advantage, and today the scattered tribes in the Amazon cheerfully greet the appearance of mature fruit [13] (Fig.1). 


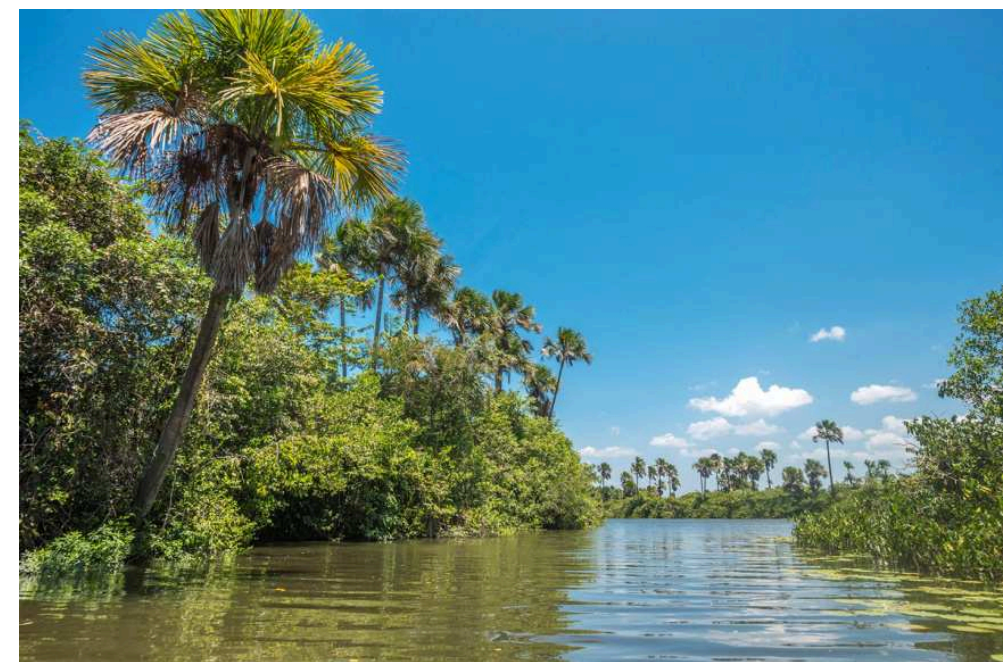

Fig. 1, Buriti palm trees, Barreirinhas city (Maranhão, Brazil). [14]

Predominantly tropical, from Mauritia genus, Arecaceae family, it is widely distributed in Brazil. According to reports of Santelli [15]: "This species is widely distributed throughout South America, occurs in Brazil in the states of Amazonas, Pará, Maranhão, Piauí, Bahia, Ceará, Tocantins, Mato Grosso, Goiás, São Paulo and the Federal District, being frequent in the humid lowlands of areas of Cerrado of Central Brazil". According to Lorenzi [16], the Buriti is the most common and abundant palm in the Brazilian territory and commonly in nearly homogeneous groups called "buritizais" (Fig. 2).

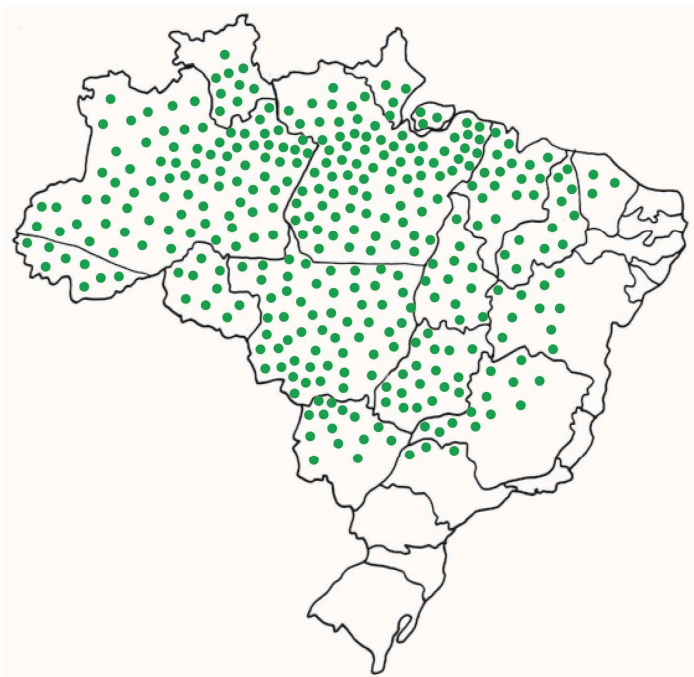

Fig. 2, Distribution of the buriti palm tree in Brazil. Adapted [16]

In Brazil, this palm is known as "miriti", "buriti", "buriti-do-brejo", "moriti”, "moriti-do-brejo" and "muritizeiro" [17]. It is a gender of robust palms, large, dioeciously, solitary, with huge fanshaped leaves, with segments of equal width of South America (Colombia, Ecuador, Peru, Venezuela, Brazil and Guyana) and Trinidad, growing in immense form of homogeneous populations on lowlands periodically flooded [12]. It has erect, cylindrical, hairless and helpless stipe; it can reach up to $50 \mathrm{~m}$ height and $50 \mathrm{~cm}$ diameter, with 20-30 leaves, measuring $5 \mathrm{~m}$ long and up to $3 \mathrm{~m}$ wide [13]. This species is a source of food, beverages, cosmetics and raw material for crafts and handiwork. The fruits are eaten in the form of juice and sweet. The petiole is used to make toys. The plant is very ornamental and can be grown for landscaping [12]. It is widely used in Brazilian handicraft, especially in the North, Northeast and Midwest regions (most abundant in regions of the biomes of the Amazon Forest and Cerrado), and popularly known as "linen or silk", corresponding to the fiber obtained from the young leaves of buriti palm. 
The collection of these leaves, locally known as "eyes", can be performed by any member of the community. At higher palm collection is performed by men while women and children remove the buds of young "buritis" (Fig. 3).

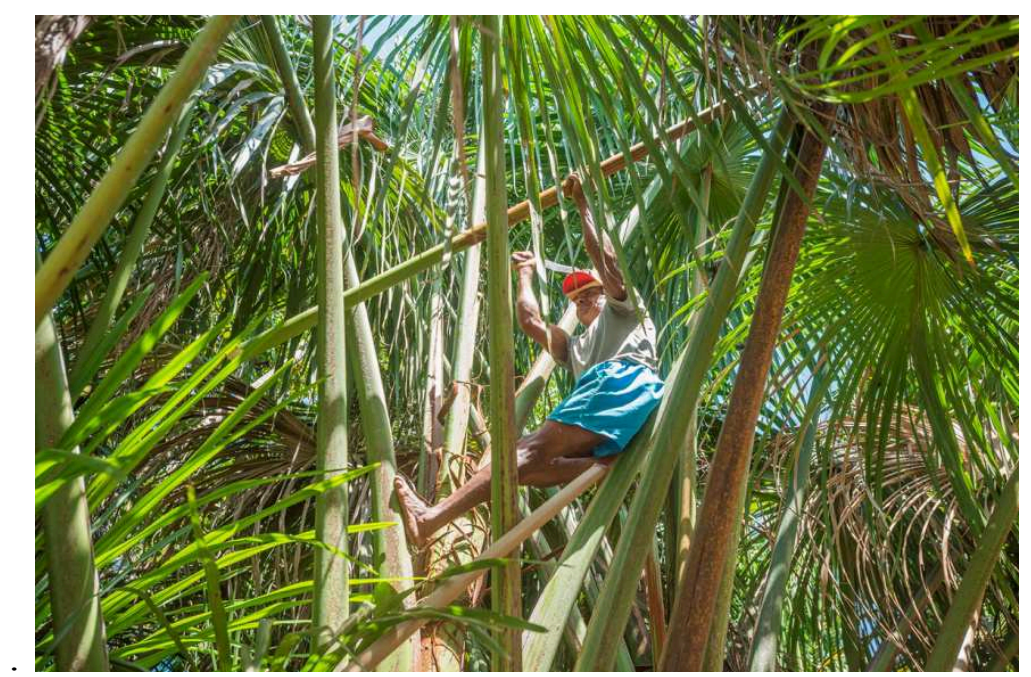

Fig. 3, Cutting of leaf of buriti. [14]

The withdrawal of new leaves is performed following the tradition of each region and, according to the experience and observation of the extraction, to preserve the palm is necessary to keep some new buds and perform the next collection only after the birth of new leaves. In addition to the management care of palm trees, the whole procedure of processing the fiber, until it becomes a product, is performed with attention to all its stages. The "linen" Buriti is a thin film of this new shredded leaf (Fig. 4). The remaining part of the sheet, i.e., the residue (called "borra") is also used in some types of products.

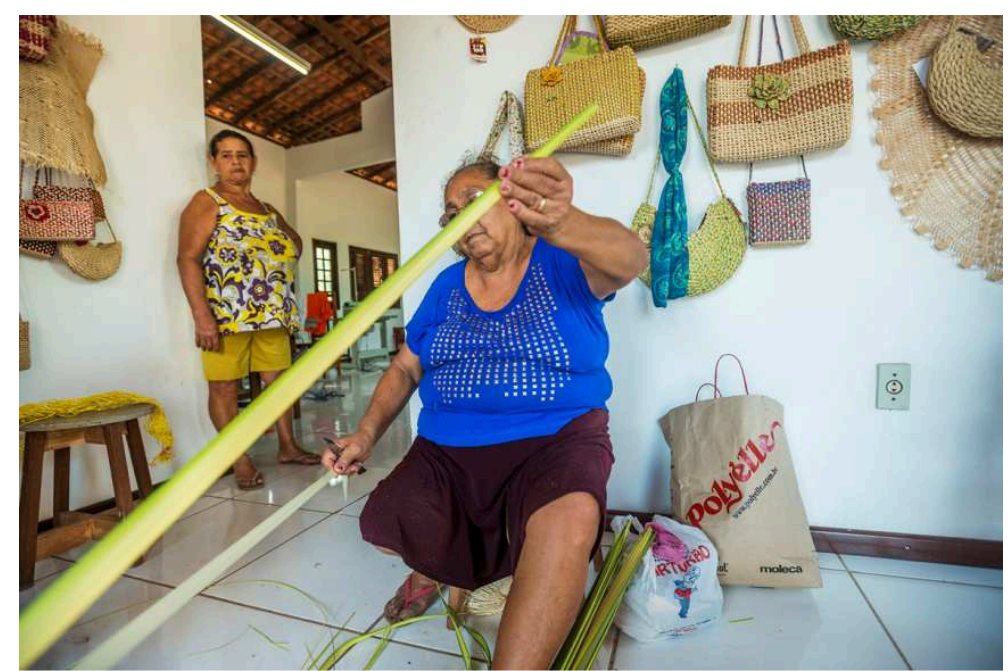

Fig. 4, Release of the buriti "linen". [14]

This linen can be cooked in pure water or with natural dyes taken from local flora and dry naturally in ventilated place and without solar incidence (Fig. 5). The next step is to transform it in a yarn ball and to start the weaving. 


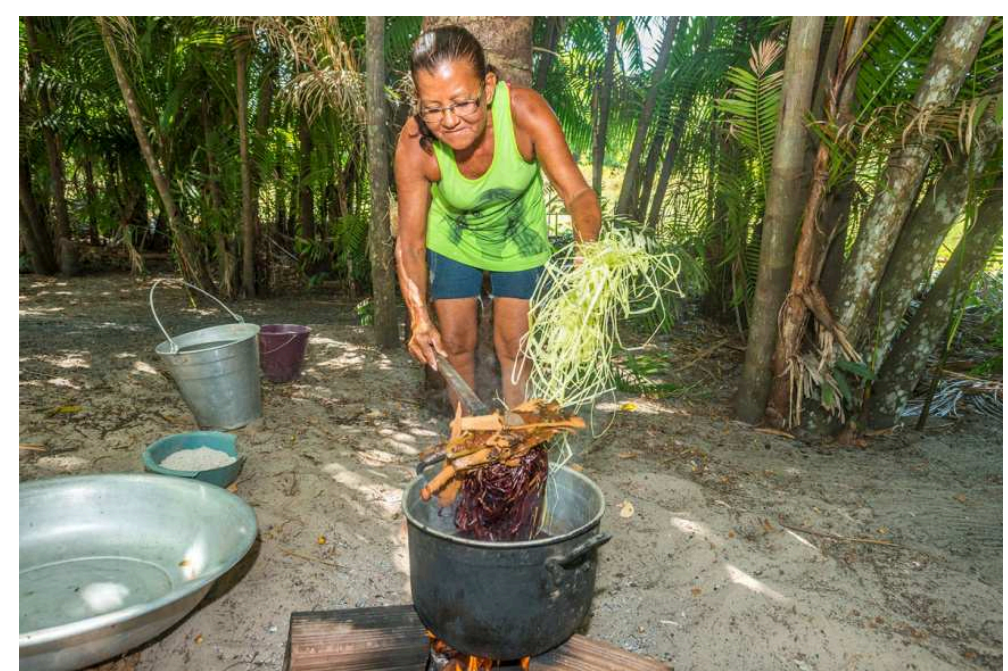

Fig. 5, Boiling of the fiber with natural dye. Marcelino community (Barreirinhas, MA, Brazil). [14]

Handicraft found in Maranhão state has rich technical diversity, outstanding design and careful workmanship, and enjoy all the parts of the leaf. These are some of the reasons why products made with buriti fiber represent an important economic role for regional communities (Fig. 6 and Fig. 7).

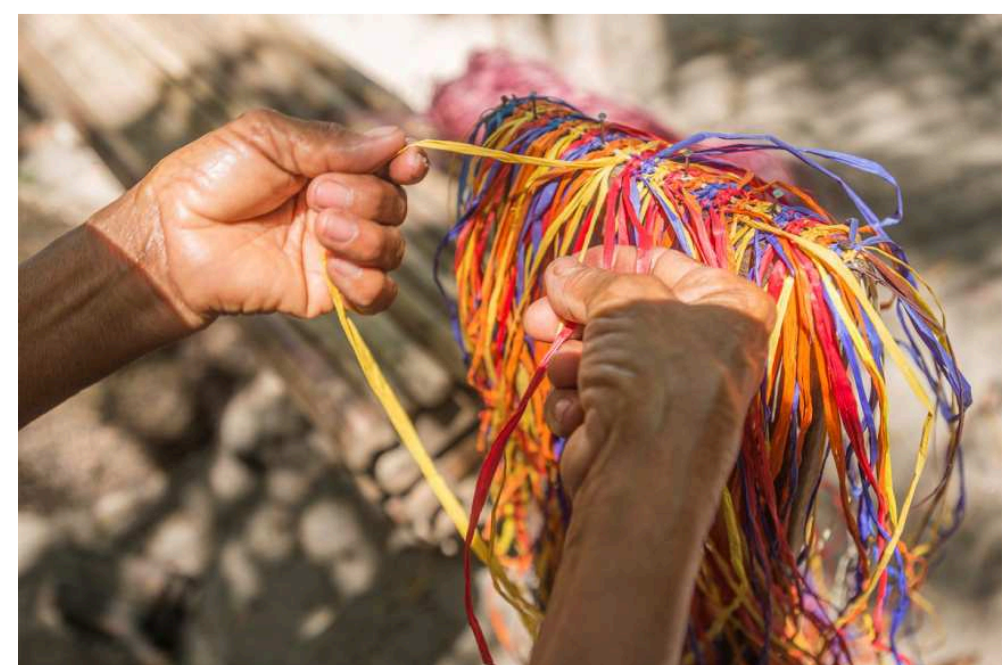

Fig. 6, Macrame technique employing buriti "linen”. Marcelino community (Barreirinhas, MA, Brazil). [14] 


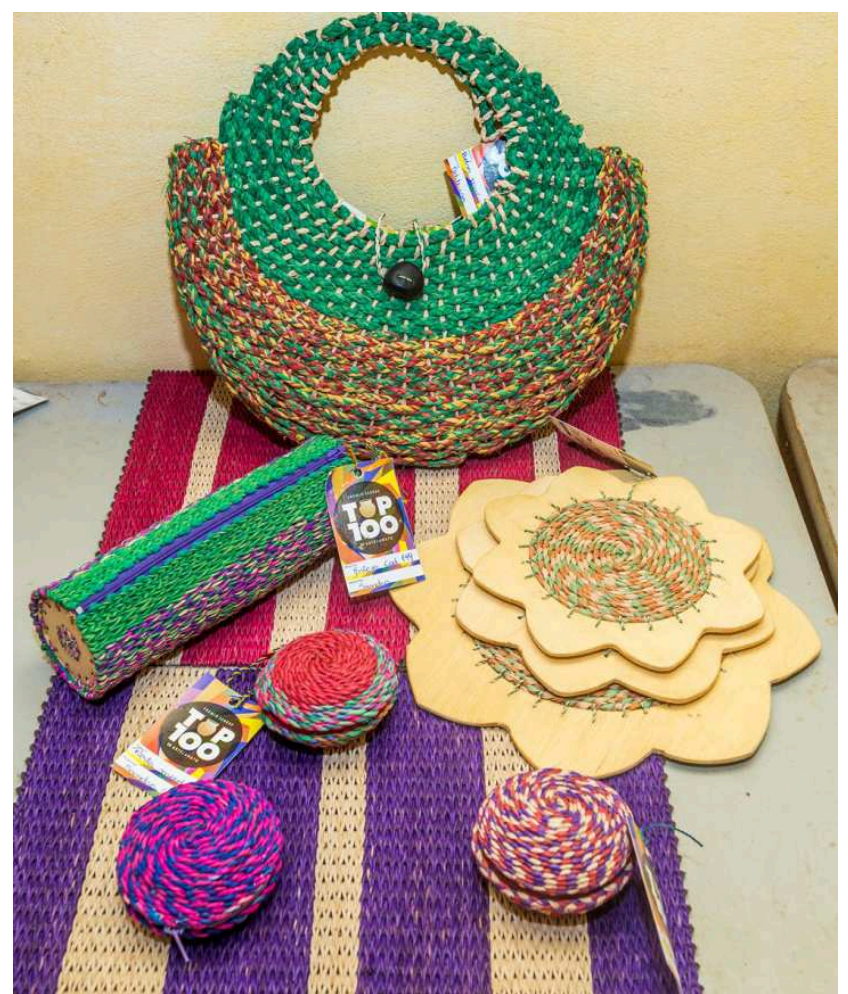

Fig. 7, Products made with buriti leaf residue ("borra"). Grupo Mulheres de Fibra (São Luis, MA, Brazil). [14]

\section{Materials and Methods}

Fibers taken from young leaves of Buriti palm trees (Mauritia flexuosa Mart.) located in Marcelino Village, situated on the bank of "Preguiça" river, Barreirinhas city, Maranhão State, Brazil, were used for this study, as geographic GPS coordinates $02^{\circ} 45^{\prime} 18,8101$ "S and $42^{\circ} 49^{\prime} 04,2782^{\prime \prime} \mathrm{W}$. The samples were collected in July 2014.

\section{Pre-treatment and immersion}

The length of the fiber in natura withdrawal of young palm tree leaf Buriti can exceed 2,000 mm. In this way, for testing of tensile properties fiber samples were cut into pieces by manual means measuring $\pm 100 \mathrm{~mm}$ (Fig. 8). They were separated into 140 units for each preparation. For the achievement of physical and chemical tests, the samples were separated into five groups: 1) in natura fibers; 2) fibers boiled by the origin community (in Barreirinhas city); 3) fibers boiled in bleach 2-2.5\% of sodium hypochlorite (Cândida Q-boa, Anhembi, Brasil) (fibers boiled in $500 \mathrm{ml}$ of water and $30 \mathrm{ml}$ of bleach for $15 \mathrm{~min}$ ); 4) fibers boiled in softener (Mon Bijou, Bombril, Brazil), boiled in $500 \mathrm{ml}$ of water and $30 \mathrm{ml}$ of fiber fabric softener for $15 \mathrm{~min}$; and 5) fibers boiled in lemon juice (fiber boiled in $500 \mathrm{ml}$ of water with half Tahiti a lemon for $15 \mathrm{~min}$ ). All the samples were placed in light protected and semi-enclosed glasses. The boiling process of the last three groups of fibers occurred in São Paulo city. Further immersion tests were performed maintaining the samples in the described conditions during 21 days. The samples were collected every 3 days, between 20 and $22 \mathrm{~h}$, with the removal of 20 units of the experiment, a total of seven samples taken in 21 days. After the sauce removal of samples they were washed and dried naturally in a cool environment without solar incidence. Then photographed on white background (Nikon Digital Camera, 12.0 megapixels, the COOLPIX S570 model, Japan) and acclimatized to the testing of traction dynamometer. For all procedures, distilled water was employed. 


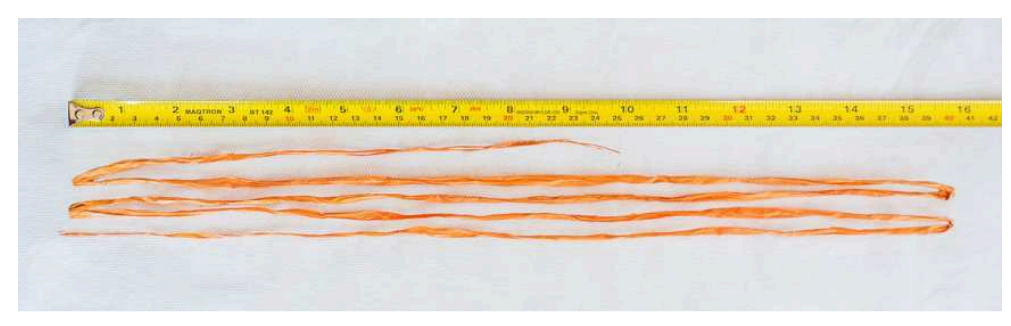

Fig. 8, Mean length of buriti fiber. [14]

\section{Tensile tests}

For each condition 20 samples were employed. The samples were conditioned individually in test tubes measuring $150 \mathrm{~mm}$ in height and previously acclimatized for a minimum of 48 hours at $20^{\circ} \mathrm{C}$ and $65 \%$ of relative humidity in climatizer (Mesdan, model M250 Climatest-RH, Italy). The determination of the lengths of the samples was performed in order to find the average of the fiber count numbers, which are needed to tensile tests. After measuring the length of the buriti fiber samples the count number was calculated. This method was adapted from ISO 1973-1995 standard [19], gravimetric method for determining the quantity of mass per length unit. The weighing of each unit fiber was performed in analytical balance (Sartorius, model ED124S, Germany).

Tensile tests were performed according to ASTM D 3 822-2001 standard [19], which is specific for testing of tensile properties of single textile fibers, employing Instron test machine (model 5569, Norwood, USA). In these tests it was determined averages, standard deviations and coefficients of variation of maximum load $(\mathrm{N})$, breaking load $(\mathrm{N})$, the break tenacity $(\mathrm{cN} /$ tex), extension at maximum load $(\mathrm{mm})$, extension at load rupture $(\mathrm{mm})$, percentage elongation at break $(\%)$ and Young' modulus (N/tex). Tenacity versus elongation percentage curves were also generated. The distance between jaws was $25 \mathrm{~mm}$, separation speed of $20 \mathrm{~mm} / \mathrm{min}$ and load cell of 1,000 $\mathrm{N}$ (or about $100 \mathrm{kgf}$ ). In all cases, rubberized grips jaws with dimensions of $2.5 \times 2.5 \mathrm{~cm}$ were used.

\section{Regain Determination}

In order to determine regain, the method was adapted from ISO/TR 6741-4:1987 standard [20]. The moisture was determined by weighing a conditioned sample $\left(20^{\circ} \mathrm{C}\right.$ and $65 \%$ relative humidity for $24 \mathrm{~h}$ ) on an analytical balance (Sartorius, model ED124S, Germany). Then drying was performed in an oven with forced air circulation (Binder FD Model 115, Germany) at $70^{\circ} \mathrm{C}$ for $24 \mathrm{~h}$ until constant weight ("overnight") and the sample was again weighed. Five repetitions of each group were analyzed.

\section{Microscopy}

The buriti fiber identification test by microscopy of longitudinal and transverse cuts was performed according to ABNT NBR 13538-1995 standard [21]. Buriti fibers were encapsulated in order to perform transverse cuts. For obtaining digital images and cell diameter in cross microscopies stereo-microscope coupled to a video camera was used. These images were captured and processed by the video system Analyzer 2000 (Mesdan, Italy).

\section{Results and discussion}

\section{Tensile Properties}

The results obtained in the tests are shown in Table 1 and Fig. 9. According the comparison between them, there is no significant difference in tensile properties associated to the previous fiber treatment. 
By comparing the tenacity and Young's modulus values for the studied species (Table 1) using the values of known textile fibers (Table 2), they are comparable to cotton, which is a fiber widely used in the textile industry. The species studied show employment in crafts and in addition, the results of tensile tests are promising for the use of this fiber as raw material for technical applications.

Table 1, Results of tensile tests. The values are expressed of average of 20 determinations, respective standard deviation and variation coefficient.

\begin{tabular}{|c|c|c|c|c|c|}
\hline Set of samples & $\begin{array}{c}\text { Count } \\
\text { Number } \\
\text { (tex) }\end{array}$ & $\begin{array}{c}\text { Rupture } \\
\text { Strength } \\
\text { (N) }\end{array}$ & $\begin{array}{l}\text { Tenacity } \\
\text { (cN/tex) }\end{array}$ & $\begin{array}{l}\text { Elongation } \\
\quad(\%)\end{array}$ & $\begin{array}{c}\text { Young's } \\
\text { modulus } \\
\text { (N/tex) }\end{array}$ \\
\hline In natura fibers & $\begin{array}{l}223.4 \pm 77.7 \\
(34.8 \%)\end{array}$ & $\begin{array}{c}64.1 \pm 28.0 \\
(43.6 \%)\end{array}$ & $\begin{array}{l}28.4 \pm 5.5 \\
(19.6 \%)\end{array}$ & $\begin{array}{l}8.3 \pm 0.5 \\
(6.8 \%)\end{array}$ & $\begin{array}{l}6.1 \pm 0.8 \\
(13.1 \%)\end{array}$ \\
\hline $\begin{array}{l}\text { Fibers boiled by the origin } \\
\text { community }\end{array}$ & $\begin{array}{l}196.9 \pm 71.7 \\
(36.4 \%)\end{array}$ & $\begin{array}{c}60.4 \pm 25.7 \\
(42.6 \%)\end{array}$ & $\begin{array}{l}31.1 \pm 7.6 \\
(24.7 \%)\end{array}$ & $\begin{array}{c}8.3 \pm 0.7 \\
(9.2 \%)\end{array}$ & $\begin{array}{l}7.2 \pm 0.6 \\
(9.5 \%)\end{array}$ \\
\hline Fibers boiled in bleach & $\begin{array}{c}199 \pm 81.8 \\
(41.1 \%)\end{array}$ & $\begin{array}{c}55.3 \pm 28.6 \\
(51.7 \%)\end{array}$ & $\begin{array}{l}27.6 \pm 7.1 \\
(25.9 \%)\end{array}$ & $\begin{array}{l}7.8 \pm 0.5 \\
(7.4 \%)\end{array}$ & $\begin{array}{l}5.9 \pm 1.1 \\
(19.9 \%)\end{array}$ \\
\hline Fibers boiled in softener & $\begin{array}{l}208.7 \pm 83.8 \\
(40.1 \%)\end{array}$ & $\begin{array}{c}49.9 \pm 31.8 \\
(63.7 \%)\end{array}$ & $\begin{array}{l}22.0 \pm 8.7 \\
(39.7 \%)\end{array}$ & $\begin{array}{l}8.6 \pm 1.8 \\
(21.5 \%)\end{array}$ & $\begin{array}{l}4.9 \pm 0.9 \\
(19.7 \%)\end{array}$ \\
\hline Fibers boiled in lemon juice & $\begin{array}{c}194.6 \pm 67.2 \\
(34.5 \%)\end{array}$ & $\begin{array}{c}58.4 \pm 25.9 \\
(44.3 \%)\end{array}$ & $\begin{array}{c}29.7 \pm 6.4 \\
(21.7 \%)\end{array}$ & $\begin{array}{c}8.5 \pm 0.5 \\
(6.4 \%)\end{array}$ & $\begin{array}{c}5.8 \pm 0.7 \\
(13.4 \%)\end{array}$ \\
\hline
\end{tabular}

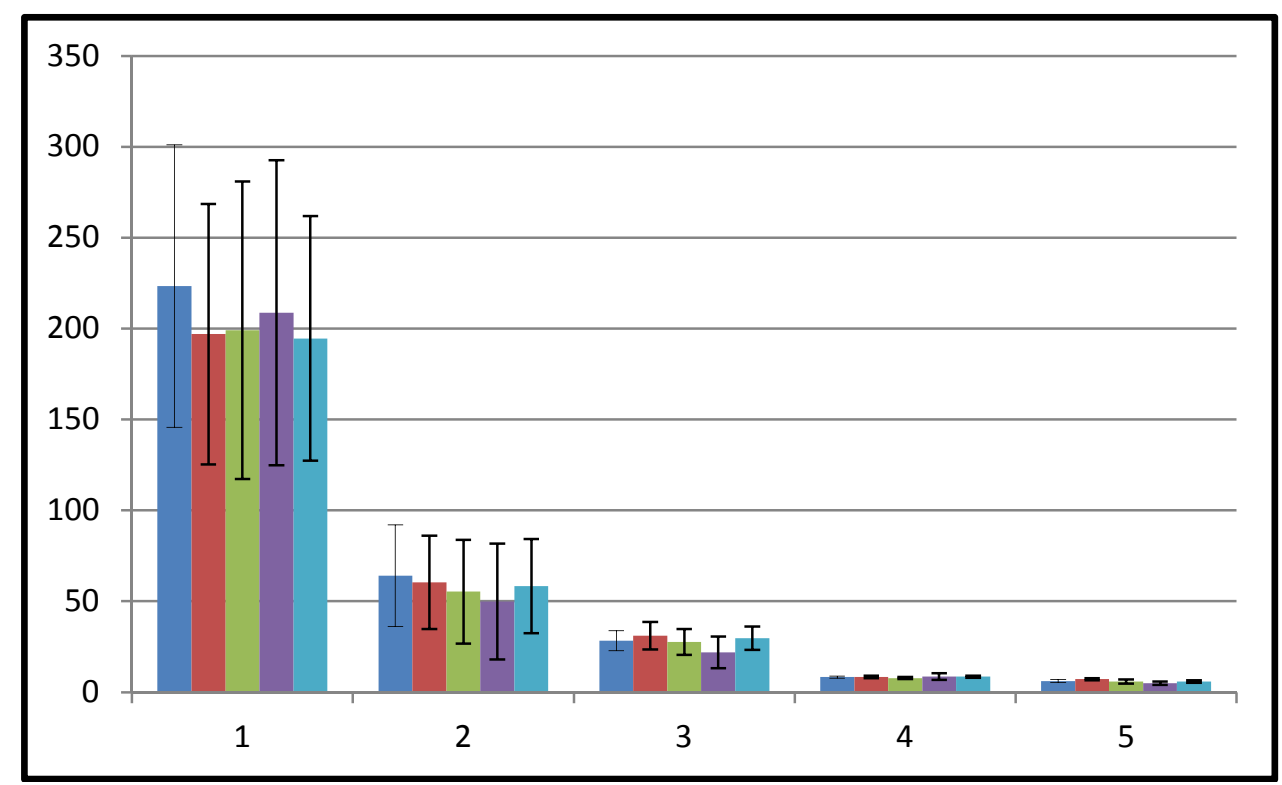

Fig. 9, Values of: (1) count number (tex); (2) rupture strength (N); (3) tenacity (cN/tex); (4) elongation (\%); Young's modulus (N/tex) corresponding to experimental conditions of: (blue): in natura fibers; (orange): fibers boiled by the origin community; (green): fibers boiled in bleach; (purple): fibers boiled in softener; (turquoise): fibers boiled in lemon juice. 
Table 2, Tenacity, elongation and Young's modulus values for species of recognized textile employability. Adapted from Kaswell, 1963 [22]

\begin{tabular}{|l|c|c|c|}
\hline Natural Fibers & $\begin{array}{c}\text { Tenacity } \\
(\mathbf{c N} / \mathbf{t e x})\end{array}$ & $\begin{array}{c}\text { Elongation } \\
(\mathbf{\%})\end{array}$ & $\begin{array}{c}\text { Young's modulus } \\
(\mathbf{N} / \text { tex) }\end{array}$ \\
\hline Cotton & $26.5-43.3$ & $3-7$ & $5.3-6.2$ \\
\hline Mercerized cotton & 30.0 & 7 & 15.5 \\
\hline Flax & $23.0-68.0$ & $2.7-3.3$ & 19.4 \\
\hline Hemp & $51.5-60.0$ & 1.8 & 17.9 \\
\hline Jute & $26.5-51.2$ & $1.7-2.0$ & 17.0 \\
\hline Abaca & $53.0-66.2$ & $2-3$ & 16.2 \\
\hline Ramie & 48.6 & $3-7$ & 12.4 \\
\hline Sisal & $35.3-44.1$ & $2-3$ & \\
\hline
\end{tabular}

\section{Regain}

The results concerning regain are in Table 3. According the comparison between them, there is a slight difference between the fibers boiled by community, in bleach and in softener (near 9.5\%) and the in natura fibers and boiled in lemon juice (near 8.4\%). This difference as well as the respective reason should be better analyzed in further tests.

Table 3, Values of regain (five determinations for each group), with respective averages, standard deviations and coefficients of variation.

\begin{tabular}{|l|c|c|c|c|c|c|c|c|}
\hline Set of samples & $\mathbf{1}$ & $\mathbf{2}$ & $\mathbf{3}$ & $\mathbf{4}$ & $\mathbf{5}$ & $\begin{array}{c}\text { Average } \\
\mathbf{( \% )}\end{array}$ & $\begin{array}{c}\text { Standard } \\
\text { deviation }\end{array}$ & $\begin{array}{c}\text { C.V. } \\
\mathbf{( \% )}\end{array}$ \\
\hline In natura fibers & 8.2 & 8.5 & 8.2 & 8.5 & 8.7 & 8.4 & 0.2 & 2.6 \\
\hline $\begin{array}{l}\text { Fibers boiled by the origin } \\
\text { community }\end{array}$ & 9.0 & 8.9 & 9.5 & 8.9 & 9.8 & 9.2 & 0.4 & 4.4 \\
\hline Fibers boiled in bleach & 9.9 & 10.1 & 9.4 & 9.8 & 9.6 & 9.8 & 0.3 & 2.8 \\
\hline Fibers boiled in softener & 9.2 & 9.1 & 9.5 & 8.6 & 8.7 & 9.0 & 0.4 & 4.1 \\
\hline $\begin{array}{l}\text { Fibers boiled in lemon } \\
\text { juice }\end{array}$ & 8.6 & 8.3 & 8.1 & 8.1 & 8.8 & 8.4 & 0.3 & 3.7 \\
\hline
\end{tabular}

\section{Microscopies of buriti fiber}

The identification of the structures of buriti fiber was observed by microscopic observation of the longitudinal and cross section of a sample. The fiber was analyzed in a longitudinal view (Fig. 10) and cross through optical microscopy (Fig. 11).

Despite of the similarities in the cross sections of studied species here and that ones from fibers of recognized textile employability, it cannot conclude, only through microscopic examination of their cross sections, the possible type of application for certain fiber. For this purpose there is the necessity of a combined analysis of results from other physical and chemical tests. However, examination of cross sections by optical microscopy also is useful to evaluate the integrity of fiber 
cellular structure and the adequacy of retting time for the extraction of the fibers. In the case of ultra-retting (when the excessive retting makes the fibers brittle and weak) the damage to cellular structures is visible such as deformation of cell shape or forming large holes [10]. In the present study, the cross microscopies corresponding to the species analyzed showed the full integrity of cell structures. This means that the retting process time was suitable for extraction of these fibers. As shown in Fig.11, the cell diameter value obtained for species in this study $(8.5 \mu \mathrm{m})$ is compatible with the values of species of recognized textile employability. According to Reddy and Yang [23], the unit cell size ranges from 12.0 to $25.0 \mu \mathrm{m}$ for cotton, 5.0 to $76.0 \mu \mathrm{m}$ for flax and from 15.0 to $25.0 \mu \mathrm{m}$ for jute.

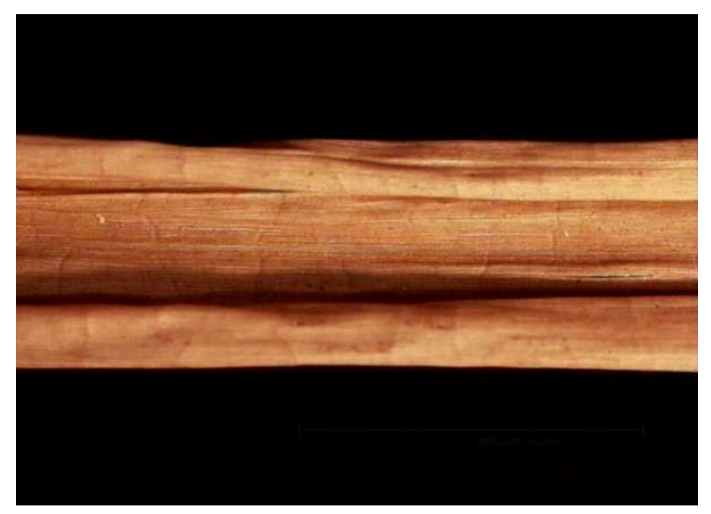

Fig. 10, Longitudinal microscopy of buriti fiber (20X magnification).

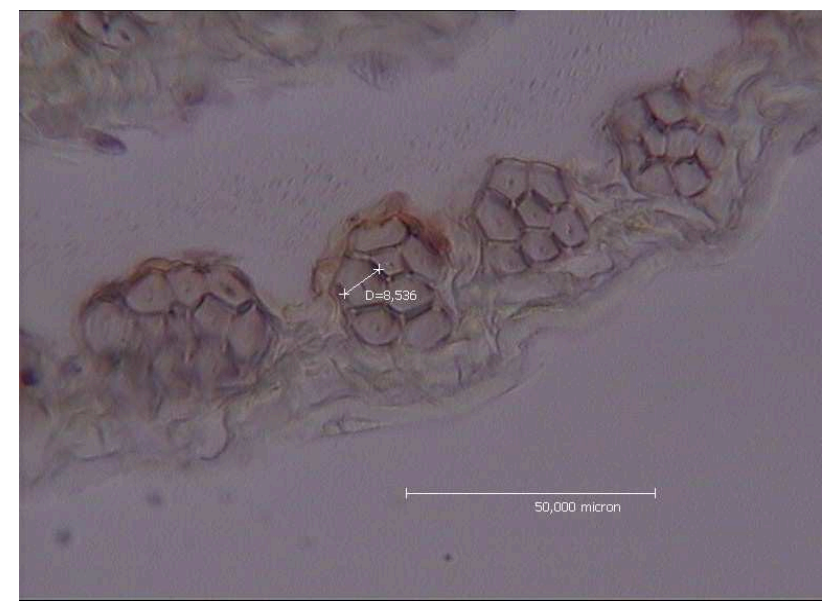

Fig. 11, Cross microscopy of buriti fiber (1,280X magnification). Indicated cell diameter of $8.5 \mu \mathrm{m}$.

\section{$\underline{\text { Immersion of buriti fiber }}$}

The results produced by immersion in water for 21 days are shown in Table 4 comparing the tenacity and Young's modulus values of the same fiber in Table 1 and Fig. 9, it is concluded that the resistance of buriti fiber has not showed variation. This preliminary test is an indicative of a possible good resistance of this fiber to the ambient weather conditions and the durability of products made from this fiber. However after immersion it in water for 21 days, a slight decrease in the elongation capacity, specially remarkable in fibers in nature and fiber with no addition of chemicals, namely fibers boiled by the origin community and Fibers boiled in lemon juice. 
Table 4, Results of tensile tests after 21 days immersion. The values are expressed of average of 20 determinations, respective standard deviation and variation coefficient.

\begin{tabular}{|c|c|c|c|c|c|}
\hline Set of samples & $\begin{array}{c}\text { Count } \\
\text { Number } \\
\text { (tex) }\end{array}$ & $\begin{array}{c}\text { Rupture } \\
\text { Strength } \\
\text { (N) }\end{array}$ & $\begin{array}{l}\text { Tenacity } \\
\text { (cN/tex) }\end{array}$ & $\begin{array}{c}\text { Elongation } \\
(\%)\end{array}$ & $\begin{array}{c}\text { Young's } \\
\text { modulus } \\
(\mathrm{N} / \text { tex })\end{array}$ \\
\hline In natura fibers & $\begin{array}{c}116.7 \pm 36.1 \\
(30.9 \%)\end{array}$ & $\begin{array}{c}26.1 \pm 9.2 \\
(35.5 \%)\end{array}$ & $\begin{array}{c}22.4 \pm 4.2 \\
(18.9 \%)\end{array}$ & $\begin{array}{l}5.4 \pm 0.6 \\
(12.3 \%)\end{array}$ & $\begin{array}{c}6.7 \pm 1.1 \\
(16.5 \%)\end{array}$ \\
\hline $\begin{array}{l}\text { Fibers boiled by the origin } \\
\text { community }\end{array}$ & $\begin{array}{c}78.8 \pm 30.4 \\
(38.6 \%)\end{array}$ & $\begin{array}{l}23.2 \pm 9.2 \\
(39.8 \%)\end{array}$ & $\begin{array}{l}29.8 \pm 5.6 \\
(19.0 \%)\end{array}$ & $\begin{array}{l}6.1 \pm 0.5 \\
(6.1 \%)\end{array}$ & $\begin{array}{l}8.4 \pm 1.2 \\
(8.4 \%)\end{array}$ \\
\hline Fibers boiled in bleach & $\begin{array}{c}98.7 \pm 46.3 \\
(46.9 \%)\end{array}$ & $\begin{array}{c}29.6 \pm 14.4 \\
(48.8 \%)\end{array}$ & $\begin{array}{c}30.2 \pm 5.2 \\
(17.3 \%)\end{array}$ & $\begin{array}{c}7.0 \pm 0.7 \\
(10.2 \%)\end{array}$ & $\begin{array}{c}7.3 \pm 0.9 \\
(12.6 \%)\end{array}$ \\
\hline Fibers boiled in softener & $\begin{array}{l}125.6 \pm 48.6 \\
(38.7 \%)\end{array}$ & $\begin{array}{c}32.0 \pm 13.9 \\
(43.4 \%)\end{array}$ & $\begin{array}{l}25.3 \pm 4.87 \\
(19.0 \%)\end{array}$ & $\begin{array}{l}7.4 \pm 0.6 \\
(9.3 \%)\end{array}$ & $\begin{array}{l}5.5 \pm 0.8 \\
(15.6 \%)\end{array}$ \\
\hline Fibers boiled in lemon juice & $\begin{array}{c}95.3 \pm 35.4 \\
(37.1 \%)\end{array}$ & $\begin{array}{c}26.7 \pm 12.3 \\
(46.1 \%)\end{array}$ & $\begin{array}{l}27.5 \pm 5.0 \\
(18.4 \%)\end{array}$ & $\begin{array}{l}6.4 \pm 0.5 \\
(8.9 \%)\end{array}$ & $\begin{array}{l}7.6 \pm 0.9 \\
(12.1 \%)\end{array}$ \\
\hline
\end{tabular}

\section{Conclusion}

Biodiversity is the exuberance of life on Earth - a seemingly endless cycle of life, death and transformation (MMA, 2014) [4].

Although the most common and widely distributed palm in Brazil and its derivatives benefit large numbers of people, between producers and consumers, little has been recorded about the characteristics of the fibers taken from the young leaves of the buriti palm. As result it is not found in the literature references for comparison between this fiber and other similar fibers employed in textiles, handicraft or industrial processes. According to the presented results in this study buriti fiber has tenacity comparable to cotton tenacity. After immersion it in water for 21 days, a slight decrease in the elongation capacity, especially remarkable in fibers in nature and fiber with no addition of chemicals, namely fibers boiled by the origin community and fibers boiled in lemon juice.

From the present results it could be considered promising the employment of buriti in new textile applications. Thus, this study could expand knowledge of Brazilian biodiversity potential to provide alternatives to the use buriti fiber in the development of new products for use in design and industry. Besides, it could collaborate in the construction of social benefits by encouraging the recovery and strengthening of local cultural identity, community organizing around the social economy and the consequent generation of income for extractive communities' fibers.

\section{References}

[1] Information on http://www.educaterra.terra.com.br (Carta de Pero Vaz de Caminha ao rei de Portugal, 1500).

[2] C. Porto, Macrocenários da Amazônia 2000-2020. Centro de Estudos Estratégicos do Ministério da Ciência e Tecnologia. Revista Parcerias Estratégicas n.12 (2001) p.186-205.

[3] Information on http://www.ibge.gov.br

[4] Information on http://www.mma.gov.br 
[5] W.R. El Banna, R.T. Fujiyama, I.P. dos Santos, L.C.O. Pereira, Fibras de bananeira como material de engenharia, Grupo de Pós-Graduação em Engenharia Mecânica da Universidade do Pará, in: XXXIX Congresso Brasileiro de Educação em Engenharia, Blumenau, 2011. Anais.

[6] D.B. Pires (Org.), Design de Moda - Olhares Diversos. SENAC, São Paulo, 2008.

[7] Information on http://www.fiemt.br

[8] T. Kanzazian (Org.), Haverá a idade das coisas leves: Design para o desenvolvimento sustentável, ed. SENAC, São Paulo, 2005.

[9] Information on http://www.horizonte.unam.mx (D. Gonçalves, Canção do Exílio, 1847).

[10] A. Henderson, G. Galeano, R. Bernal, Field guide to the Palms of the Americas, Princeton University Press, New Jersey, 1995.

[11] G. Bondar, Palmeiras do Brasil. Secretaria da Agricultura do Estado de São Paulo - Instituto de Botânica, São Paulo, 1964.

[12] H. Lorenzi, L.R. Noblick, F. Kahn, E. Ferreira, Flora Brasileira - Aracaceae (Palmeiras), ed. Plantarum, Nova Odessa, 2010.

[13] M.P. Corrêa, Dicionário das plantas úteis do Brasil e das exóticas cultivadas, ed. Imprensa Nacional, Rio de Janeiro, v. I, 1984.

[14] M. Goulart. Photos. Personal collection, 2014.

[15] Santelli, P. (2005). Fisiologia Pós-colheita de frutos das palmeiras Syagrus olearecea (Mart.) e Mauritia vinífera (Mart.). Brasília. 86p. Dissertação (Mestrado) - Instituto de Biologia (IB), Universidade de Brasília.

[16] H. Lorenzi, H.M. Souza, J.T. Medeiros-Costa, L.S.C. de Cerqueira, E. Ferreira, Palmeiras Brasileiras e Exóticas Cultivadas, ed. Editora Plantarum, Nova Odessa, 2004.

[17] J.C. Medina, Plantas Fibrosas da Flora Mundial, ed. Instituto Agronômico, Campinas, v. I, 1959.

[18] International Standards Organization, ISO 1973-1995: Textile fibres - Determination of linear density - Gravimetric method and vibroscope method, 8 p, 1995.

[19] American Society of Testing Materials, ASTM D 3 822-2001, Standard test methods for breaking strength and elongation of cotton fibers (Flat Bundle Method), West Conshohocken, 2006, 8p, 2001.

[20] International Standards Organization, ISO/TR 6741-4 -1987: Textiles - Fibres and yarns Determination of commercial mass of consignments - Part 4: Values used for the commercial allowances and the commercial moisture regains, 6 p, 1987.

[21] Associação Brasileira de Normas Técnicas, ABNT NBR 13538:1995. Material têxtil - Análise qualitative, 20 p, 1995.

[22] E.R. Kaswell, Wellington Sears Handbook of Industrial Textiles, Massachusetts Institute of Technology (MIT) e Wellington Sears Company, Cambridge, United States, 1963.

[23] N. Reddy, Y. Yang, Properties and potential applications of natural cellulose fibers from cornhusks, Green Chemistry, v. 7, p. 190-195, 2005. 